\title{
Polska literatura najnowsza i Holokaust - edukacyjny potencjał fikcji?
}

\author{
Polish Contemporary Prose and the Holocaust - \\ Educational Opportunities Granted by Fiction
}

\begin{abstract}
Aвstract: The article contains considerations regarding memory of the Holocaust in Polish contemporary prose and analyses the arguments for and against fictitious representations of the Shoah. The author discusses the changes in treating fiction which narrates the history of Jewish people during the Second World War - from works of fiction published after the war (e.g. Wielki Tydzień by Jerzy Andrzejewski) to popular thrillers written in the 21st century. The main part of this article is devoted to a novel Tworki written by Marek Bieńczyk in 1999, telling a story of young people - Poles and Jews - employed in a mental hospital during German occupation. The novel was at the centre stage of discussion about relationship between fiction and the Shoah theme, yet the author of the article argues that it may serve as an important stepping stone in exemplifying history. This literary vision of the Holocaust (defined as "pastoral thriller") shows educational possibilities of fiction.
\end{abstract}

KEY WORDS: Shoah, Tworki, Bieńczyk, prose, contemporary literature, fiction, education

Wartość edukacyjną mają w sposób oczywisty i niekwestionowany świadectwa ofiar i świadków Zagłady - z reguły potwierdzają to przekonanie współcześni młodzi odbiorcy. Dla wielu urodzonych już w czasach transformacji, w ostatnich latach XX wieku są one także, co zrozumiałe, jedyną możliwą i uprawnioną reprezentacją Wydarzenia, choć zawsze ułomną, fragmentaryczną, różnorako ograniczoną. Natomiast status fikcyjnych opowieści przedstawiających czasy Holokaustu od początku budził kontrowersje - nie tylko uznawano je za nieprawomocne, ale nade wszystko niestosowne, pozbawione etycznych ufundowań, 
a co za tym idzie - zbędne, redundantne, niepotrzebne. Jednak, jak przekonuje Dorota Krawczyńska: „Niezaprzeczalna, szczególna moc relacji pochodzącej ze środka zdarzeń i stanowiącej dokument osobisty przeciwstawiana może być wiarygodności uogólnienia powstałego po latach, naznaczonego niekiedy dążeniem do wyjaśniania zdarzeń i przeżyć”. Tak rozumiana fikcja może objawiać swój edukacyjny potencjał.

Przełom XX i XXI wieku przyniósł zalew fikcyjnych, różnokodowych tekstów budowanych na pamięci o Zagładzie, także takich, które ocierały się o kicz i adresowane były do odbiorców kultury masowej. Jednak czytelnicy przyzwyczajeni do szacunku dla opowieści źródłowych przyjmowali takie narracje $\mathrm{z}$ reguły $\mathrm{z}$ nieufnością i rezerwą ${ }^{2}$. Po upływie trzydziestu lat od historycznego 1989 roku możemy prześledzić przemiany w sferze nadawczo-odbiorczych relacji związanych z reprezentacją Szoa w polskiej literaturze i kulturze najnowszej3. Trudno dziś uwierzyć, że dopiero w połowie lat 80. XX wieku temat Holokaustu powrócił - czy też pojawił się - w obiegach zbiorowej komunikacji, w ramach różnych dyskursów i odmiennych poetyk; były to między innymi: słynny esej Jana Błońskiego z „Tygodnika Powszechnego”, drugoobiegowy wywiad z Markiem Edelmanem ${ }^{5}$, ale i jedno z opowiadań Janusza Andermana z uznanego za obrazoburczy w stosunku do opozycyjnego etosu tomu Kraj świata ${ }^{6}$.

Temat ten podjął Krzysztof Kieślowski w ósmej odsłonie Dekalogu z 1988 roku, ale pojawił się on też zaledwie rok później w ujęciu komediowym w niezwykle popularnym (w obu znaczeniach słowa) filmie Mirosława Borka Konsul. Kieślowski ukazał kameralny, rozegrany na półtonach dramat dwóch

${ }^{1}$ D. Krawczyńska: Wstęp. W: Literatura polska wobec Zagłady (1939-1968). Red. S. BuryŁa, D. Krawczyńska, J. Leociak. Warszawa 2016, s. 23. Krawczyńska rozwija dalej myśl: „Zarzuty stawiane narracji nadającej doświadczeniu Zagłady sens i wartość logiczną, porządkującej z pozoru przypadkowe zdarzenia w opowieść mającą swój początek i kres, paraliżować mogą wszelkie próby refleksji metaliterackiej, wyróżniającej się wszak skłonnością do syntetyzowania i poszukiwania (czy wręcz konstruowania znaczeń)" (tamże, s. 23-24). Badaczka zarysowuje dzieje sporu o miejsce fikcji w reprezentacjach Zagłady i ukazuje jego nierozstrzygalny charakter.

${ }^{2}$ Zob. A. NasiŁowska: Literatura okresu przejściowego 1975-1996. Warszawa 2013, s. 75-79.

${ }^{3}$ Należy na wstępie podkreślić, że ze względu na uwarunkowania historyczne i społeczne przemiany funkcjonowania tematu Zagłady w obrębie polskiej komunikacji zbiorowej zachodziły w innym trybie (i rytmie) niż w kulturze Zachodu - z reguły odsłaniały lokalną specyfikę i odrębność dziejowych doświadczeń.

${ }^{4}$ J. BŁoński: Biedni Polacy patrza na getto. „Tygodnik Powszechny” 1987, nr 2.

${ }^{5}$ Co było znaczące w getcie? Nic! Nic! Nie mówcie bzdur! Z Markiem Edelmanem rozmowę przeprowadzili wiosną 1985 r. Anka Grupińska i Włodzimierz Filipek dla drugoobiegowego, ukazującego się nieregularnie, pisma poznańskiego oddziału Solidarności Walczącej „Czas” (1985, nr 4/5).

${ }^{6}$ J. Anderman: Poczucie. W: Tenże: Kraj świata. Warszawa 1987. Studentom w latach 90. podczas omawiania tego tomu właśnie wskazane opowiadanie sprawiało największe problemy interpretacyjne - w odróżnieniu od tych, w których dochodziło do demitologizacji gestów antysystemowego sprzeciwu. 
osób, dotyczący tego, że jedna nie udzieliła drugiej pomocy w czasie okupacji. W Konsulu przedmiotem satyrycznego oglądu była między innymi pazerność współczesnych potomków chłopów, którzy dla spodziewanych korzyści majątkowych kłamali na temat pomocy udzielanej Żydom przez swoich przodków podczas wojny, a w konsekwencji padli łupem oszusta.

Przełom wymusił nie tyle zmianę, ile modyfikację kanonu Zagłady, co przekonująco ukazała w swoim studium Marta Tomczok ${ }^{7}$ - przyczynił się do zmiany nawyków czytelniczych, przede wszystkim trybu i strategii lektury. Problematyka polsko-żydowska, w czasach PRL-u brutalnie usuwana $\mathrm{z}$ pola widzenia wspólnoty, zaczęła powracać i niejako przesączać się przez pokłady niepamięci oraz niewiedzy - i tej budowanej wcześniej w myśl odgórnych nakazów ideologicznych (także w ramach szkolnej edukacji), i tej wyrastającej z kompensacyjnych potrzeb świadków oraz współwinnych Holokaustu. W latach 90. literatura zaczęła zrazu przypominać o wieloetnicznym charakterze II Rzeczpospolitej. Był to czas - jak określiła Tomczok - „metonimii Zagłady” ukazujących ją jako „Wzniosły obiekt ideologii niewyrażalności”. Dla czytelników stały się one opowieściami o świecie, w którym „bezboleśnie” odzyskiwano pamięć o obecności żydowskich współobywateli, o współżyciu we wspólnotach lokalnych (najczęściej kresowych), o koegzystencji sprzed czasów Holokaustu - te bowiem pozostawały okresem nieopowiedzianym, pozostawionym niejako w planie koniecznej czy oczywistej wiedzy odbiorcy.

W latach 90. XX wieku przywrócono do obiegów komunikacyjnych nostalgiczne teksty emigracyjne, takie jak choćby Pierścień z papieru Zygmunta Haupta, ale powstawały też fikcyjne opowieści o przedwojennej historii kraju, pisane przez potomków dawnych mieszkańców wschodnich Kresów Polski. Popularną wówczas książką był na przykład Biały kamień Anny Boleckiej, gdzie autorka odtwarzała domyślne losy swojego Pradziadka, a ich tłem uczyniła wieloetniczną, a przy tym arkadyjską społeczność przedwojennej Rzeczpospolitej. Owe metonimiczne narracje nie burzyły zbiorowych mitów. Ich fikcyjność zasadzała się na przemilczeniu nie tylko rzeczywistych konfliktów rozsadzających od wewnątrz idealizowane literacko wspólnoty, ale przede wszystkim będącego ich konsekwencją tragicznego przebiegu zdarzeń z czasów wojny. Potwierdzały również intuicyjne przeświadczenia o braku rzeczywistego zapotrzebowania na wywoływane przez literaturę silne afekty - ból spowodowany usuwaną w niepamięć przeszłością ukazywaną poprzez zestawy estetycznych przesłon przestawał ranić (czy choćby doskwierać).

W latach 90. opowieści o zniszczeniu przedwojennego świata, zamiast wywoływać współmierne emocje, zdawały się skłaniać do konwencjonalizacji odbioru

${ }^{7}$ M. Томсzок: „Opowiadanie jest stałym bytu cieniem”. Kilka uwag o kanonie Zagłady w literaturze najnowszej. „Narracje o Zagładzie” 2015, nr 1, s. 75-95.

${ }^{8}$ Tamże, s. 85. 
w nostalgicznym rytuale oraz niemal natychmiastowego spychania ich na margines literackiej komunikacjị. Fikcja - przybierająca również formy kreowanych w celach autoterapeutycznych wspomnień - pozwalała pogodzić się z przeszłością. Równocześnie jednak prowadzono badania historyczne, naukowe, poszukiwania dziennikarskie, dokumentalistyczne, które poszerzały także potoczną wiedzę o przebiegu Holokaustu. Fikcja w tym układzie epistemologicznym stawała się modelem (nie modelowym ujęciem życiorysów i zdarzeń, lecz projektowanym wzorcem sytuacji nadawczo-odbiorczej w ramach interpretacyjnej wspólnoty) składanym $\mathrm{z}$ istniejących $\mathrm{w}$ zbiorowej świadomości faktów - selektywnie dobieranych, przemieszanych i hierarchizowanych. Zadaniem nadrzędnym zdawało się dążenie do samopoznania - jako społeczności obywateli kraju zmiecionego z powierzchni ziemi.

W takich realiach komunikacyjnych - co nie budzi dziś wątpliwości książce Jana Tomasza Grossa Sąsiedzi... przypadła rola tekstu przełomowego ${ }^{10}$, zapoczątkowującego serię podobnych świadectw. Odtąd podczas budowania fikcji powieściowych nie można było pomijać nabytej wiedzy. Niezwykle ważne z punktu widzenia zbiorowego odbioru okazało się nagłośnienie publikacji, jej emocjonalne, biegunowo zróżnicowane waloryzowanie - w efekcie wszyscy znali nie tylko nazwisko autora i tytuł, ale i treść tomu, nawet jeśli go nie czytali. Opowieści o Szoa rozgrywające się w przestrzeni destruowanego przez paroksyzmy Historii życia zbiorowego oraz w przestrzeni prywatnej, jednostkowych doświadczeń egzystencjalnych, budowane przecież od początku na podstawie znanych relacji autobiograficznych, wspomnień i dokumentów, nie mogły już w wieku XXI pomijać kwestii współudziału Polaków w zbrodni - także wtedy, gdy usiłowały temu zaprzeczyć.

Świadectwa zarówno ofiar, jak i obserwatorów, a nawet sprawców - odkrywane, wznawiane, tłumaczone - stanowiły wówczas rosnący w przyspieszonym tempie zbiór zapisów doświadczeń, zjawisk, procesów bardzo różnorodnych, niewyselekcjonowanych, jednak w dużej mierze powtarzalnych. Fikcja natomiast wykorzystywała właśnie ową powtarzalność, przekształcając ją w przewidywalność przebiegu losów bohaterów i układu powieściowych fabuł. Stawała się tym samym specyficznym sprawdzianem wiedzy o przeszłości albo wyzwaniem do jej zgłębiania. Natomiast nakłanianie odbiorców w ramach komunikacji literackiej do poznawczego namysłu nad przebiegiem Zagłady łączyło się zawsze z próbą poruszenia emocji. Niejednokrotnie także miało na celu uwrażliwienie

9 Zob. P. Czapliński, P. Śliwiński: Literatura polska 1976-1998. Przewodnik po prozie i poezji. Kraków 1999, s. 248-252.

${ }^{10}$ J.T. Gross: Sąsiedzi. Historia zagłady żydowskiego miasteczka. Sejny 2000. Co znamienne, jeszcze przed ukazaniem się tej książki pojawiały się głosy (również wśród studentów kierunków polonistycznych) o swoistej nadreprezentacji tematyki żydowskiej w polskiej (nauce o) literaturze. Świadczyło to o skali nieprzygotowania zbiorowości na nadchodzący za sprawą owej publikacji przełom. 
na problemy inności, obcości i wykorzenienia w wymiarze bardziej lokalnym niż uniwersalnym, choć jest to nadal projekt skazujący twórców na ciągłe poszukiwanie odpowiednich artystycznych rozwiązań i niekończący się wysiłek drążenia niewydolności języka. Dydaktyczny potencjał fikcji (wprawdzie nie zawsze łączący się z artystyczną rangą) mógł więc wzrastać wraz z pogłębianiem się świadomości zbiorowej budowanej na rozwoju wiedzy opartej na faktograficznych ujęciach Holokaustu i jedynie na tym tle mógł przynosić pozytywne skutki. Tylko bowiem w zderzeniu $\mathrm{z}$ gruntowną wiedzą o przebiegu Zagłady możliwe jest wykorzystywanie fikcyjnych opowieści w celu przekształcania zbiorowej świadomości.

Świadomość odbiorców literatury musiała zmienić się w sytuacji „katastrofy wstecznej”, definiowanej przez Przemysława Czaplińskiego jako niegdysiejszy pożar i trzęsienie ziemi, które dziś dopiero objawia pełnię swej destrukcyjnej siły:

[...] taki pożar i takie trzęsienie ziemi są możliwe - niegdyś niezauważone, więc nierzeczywiste, a rzeczywiste dopiero wtedy, gdy wreszcie zauważone. To właśnie katastrofa wsteczna. Świadkowie nie wiedzieli, gdy trwała, nie rozpoznali jej istoty, nie wymyślili środków zapobiegawczych na przyszłość. Kiedy po jakimś czasie ich potomkowie odzyskują zdolność widzenia i rozumienia, kiedy opracowują środki zaradcze, katastrofa, która już kiedyś nastąpiła, zaczyna dziać się powtórnie - rozprzestrzeniając się we wszystkich kierunkach ${ }^{11}$.

Ponowna lektura znanych wcześniej tekstów i tych, które wówczas publikowano, została zdeterminowana przez nakaz nowego emocjonalnego otwarcia na problematykę Zagłady oraz nowe odczytanie relacji między współobywatelami II Rzeczpospolitej - nie tylko w czasach okupacji.

Dopiero $\mathrm{w}$ wieku XXI mogły powstać powieściowe horrory o tematyce zagładowej - określane przez Przemysława Czaplińskiego jako „system artykulacji”, którego funkcją jest „przeprowadzenie swoistego eksperymentu z zakresu wyrażalności tego, co przerażające"12, a zarazem pozwalające odsłonić mechanizmy wspólnotowego wyparcia. Za kolejny etap (czy też podzbiór) tego typu narracji można uznać horrory ratownicze. Marta Tomczok dostrzegła niespodziewaną zbieżność projektu Czaplińskiego z koncepcją historii ratowniczej Ewy Domańskiej ${ }^{13}$, realizowaną we współczesnych powieściach, w których groza przeszłości łączy się z próbami ratowania teraźniejszości - choć z reguły w wy-

${ }^{11}$ P. Czapliński: Katastrofa wsteczna. „Poznańskie Studia Polonistyczne. Seria Literacka” 2015, nr 25, s. 37.

${ }^{12}$ P. CZApliński: Zagłada jako horror. Kilka uwag o literaturze polskiej 1985-2015. „Zagłada Żydów. Studia i Materiały" 2016, nr 12, s. 379.

${ }^{13}$ E. Domańska: Historia ratownicza. „Teksty Drugie” 2014, nr 5, s. 12-26. 
miarze regionalnym ${ }^{14}$. Forsują one obraz zmienionej wspólnoty wyobrażonej, a ich pozytywnym bohaterem jest współczesne medium: postać, która potrafi połączyć się i porozumieć z „żywymi zmarłymi”, i czyni zarazem wszystko, by ocalić dzisiejsze więzi w lokalnych społecznościach. Horror ratowniczy ukazuje zatem dzieje polsko-żydowskiego sąsiedztwa, jak dowodzi Tomczok, „w kategoriach winy i kary, przemycając, niekiedy bezwiednie, chrześcijański scenariusz odkupienia"15.

Intencją nieustannego przepisywania tej samej historii w zmieniających się warunkach politycznych i społecznych, dla różnego typu (także tej nowej, dorastającej w innej sytuacji komunikacyjnej) publiczności, było przede wszystkim wzrastające pragnienie dopełnienia zerwanego aktu komunikacji, nawiązania kontaktu z jak największą liczbą czytelników, stałego poszerzania grona odbiorców potrafiących wsłuchać się z uwagą w opowieść, dotrzeć do sedna przekazu. Fikcja może być w takim ujęciu pojmowana jako szczególne wyzwanie, nieunikniona reakcja na ślady, pamiątki, świadectwa przeszłości - tym samym pamięć minionego czasu przekształca się z pozostałości w zadanie, którego nie wolno odrzucić. Z tego trudnego, ale zarazem koniecznego zadania wywiązuje się nieodmiennie - szczególnie w polskich realiach - proza poświęcona tematyce zagładowej. A to właśnie język (narracja, opowieść, również ta fikcjonalna, interioryzowana w akcie lektury) zdolny jest przekształcać byty osobowe - autora, ale też bohatera oraz odbiorcy - w ślad, przetwarzać je, by utrwalać, a więc ocalać przed przemijaniem, a także wydobywać z milczenia ${ }^{16}$.

Tym samym zadaniem fikcji - już od pierwszych, budzących do dziś kontrowersje prób z czasów wojny (takich jak Wielki Tydzień Jerzego Andrzejewskiego ${ }^{17}$ ) czy tużpowojennych, obciążonych różnymi stłumieniami (jak na przykład Samson Kazimierza Brandysa ${ }^{18}$ ) - było ocalanie podmiotowości, i to zarówno bohaterów utworów, jak i ich twórców, skierowane ku adresatom współtworzącym okaleczoną wspólnotę. Ocalanie nie poprzez autentyzm świadectwa, lecz przez budowanie fikcyjnych, spisywanych po części „ku przestrodze i nauce”, wątków i układów fabularnych. Jednostkowość kreowanych doświadczeń nie miała

14 Zob. M. Tомсzок: Złoto i dzieci. Polski horror ratowniczy. W: Historie i narracje. Od historii lokalnej do opowieści postantropocentrycznej. Red. R. MAKARsKA. Kraków 2019, s. 15-30. Badaczka wzięła na warsztat powieści niejako „peryferyjne” (w odróżnieniu od powszechnie znanej Nocy żywych Żydów Igora Ostachowicza), o wyrazistej lokalności, takie jak Oszpicyn Krzysztofa A. Zajasa, Wizja lokalna Włodzimierza Erlicha czy Czarne liście Mai Wolny.

15 Tamże, s. 28.

16 Zob. M. Czermińska: Autor - podmiot - osoba. Fikcjonalność i niefikcjonalność. W: Polonistyka w przebudowie. Literaturoznawstwo - wiedza o języku - wiedza o kulturze - edukacja. Zjazd Polonistów, Kraków, 22-25 września 2004. T. 1. Red. M. Czermińska i in. Kraków 2005, s. 215-217.

17 Zob. S. BuryŁa, D. Krawczyńska: Proza. W: Literatura polska wobec Zagłady (19391968)..., s. $459-460$.

18 Zob. tamże, s. 488-494. 
zmieniać się $\mathrm{w}$ uogólnienie, nieuprawnione uniwersalizowanie żydowskiego czy polskiego „losu”, lecz służyła ich zapisywaniu, utrwalaniu w możliwym do przekazania kształcie.

Każda lektura bywa niedoczytaniem - stawać się jednak zawsze może wydobywaniem ze wspólnej niepamięci lub sfer wyparcia doświadczeń przeszłości, a przede wszystkim wydobywaniem z niej osób, istot ludzkich, współbraci, nade wszystko zaś zdejmowaniem z nich piętna obcości i inności. Dzieje się tak pod jednym warunkiem - konieczny jest szczególny „współudział” odbiorcy gotowego uznać prawomocność, a zarazem fortunność artystycznych poszukiwań twórcy i odnaleźć w nich rodzaj wzorca nie tylko dla własnych działań, ale i dla wspólnotowych postaw. Anna Łebkowska w artykule zatytułowanym Poznawanie siebie i poznawanie innego... wskazała najczęstsze zabiegi artystyczne służące kreowaniu „podwójnych” portretów, które pozwalają zarówno podejmować wyzwanie samopoznania, jak i uczyć odkrywania, rozumienia Innych oraz współodczuwania z nimi. Przykładowym zabiegiem jest mediatyzacja przejawiająca się w rozbudowywaniu sfery zapośredniczeń (odsłaniającym pęknięcie między pragnieniem poznania a jego niemożliwością). Podobnym w skutkach działaniem może być $\mathrm{z}$ jednej strony oscylacja, ostrożne zakreślanie projektów cudzej świadomości, a z drugiej proliferacja, czyli mnożenie punktów widzenia i uruchamianych języków ${ }^{19}$. Działania artystyczne twórców, służące kreowaniu podwajanych portretów siebie poprzez innego, wpisują się w odmianę określoną przez badaczkę jako dyslokacja ${ }^{20}$. Zachodzi ona wtedy, gdy w literaturze wymiar epistemologiczny przecina się z etycznym:

„Ja" rozproszone, odpryskowe, może dążyć do scalenia w autonarracji, ale w oparciu o „inność" - równie niepochwytną. Droga wiedzie od poznania „innego" do samopoznania; od nakładania wizerunków „ja” na „innych” do odtwarzania wielości w sobie. A zatem literatura daje szansę przemieszczenia stabilnych konstruktów, odsłaniając możliwość przeczucia epifanii ${ }^{21}$.

Anna Łebkowska podkreślała, że wskazana przez nią proliferacja, przejawiająca się poprzez nadmiar uporządkowań naddanych, nawarstwianie perspektyw widzenia świata, mnożenie fabuł i poziomów metafikcji, staje się szczególnym wyzwaniem dla odbiorcy. Badaczka podobnie dookreślała oscylację, która służy

${ }_{19}$ Por. A. Łebkowska: Poznawanie siebie i poznawanie innego. Wobec inności literatury. W: Polonistyka w przebudowie..., s. 243-245.

${ }^{20}$ Za niemal wzorcową realizację wszystkich wspomnianych zabiegów można uznać Tworki Marka Bieńczyka - oprócz oczywistej mediatyzacji oraz proliferacji (szczególnie uciążliwej dla odbiorców doby Internetu) w powieści można wskazać oscylację (np. ostrożne kreowanie wspólnego Jurkowi i Soni upodobania do „amerykańskiego typu urody”, które stanęło na przeszkodzie ich hipotetycznemu związkowi) czy dyslokację prowadzącą także do destabilizacji stereotypowych ujęć czasów okupacji i żyjących wówczas ludzi.

${ }^{21}$ A. Łebrowska: Poznawanie siebie i poznawanie innego..., s. 247. 
według niej bardziej „gestowi zatrzymania” niż ingerencji, a lęk przed redukcjonizmem oraz respekt dla inności prowadzą do wydobywania osobowego charakteru relacji między ,ja” i „nie-ja”22.

Twórcy, dążąc za każdym razem do tekstowego spotkania z Innym, także Innym w sobie, zakreślają nieprzerwanie kruche i przemieszczające się granice tożsamości własnej (jednostkowej i zbiorowej), zatem nie unieruchamiają jej w akcie poznania, lecz oddają odbiorcom w specyficznie „niegotowej” formie. Przekształcanie cudzych historii w tekst literacki, tematyzowane również jako akt rekonstrukcji miejsc utraconych, zapomnianych, startych $\mathrm{z}$ aktualnych map, odsłania niejednokrotnie swoje edukacyjne - bo nastawione na przebudowę zbiorowej świadomości - przeznaczenie.

W takim kontekście można czytać Tworki Marka Bieńczyka, utwór, który nieodmiennie, od czasu publikacji w 1999 roku, pozostaje w centrum sporów o miejsce fikcji w piśmiennictwie zagładowym. Historie miłości, erotycznych przygód, przyjaźni i rywalizacji młodych mieszkańców okupowanego kraju z pozoru błahe, marginalne, „zmyślone” - były postrzegane jednak (już w pierwszych reakcjach odbiorczych) jako materia do pogłębionego namysłu nad zagadnieniami tożsamości. Przez dwadzieścia lat, które upłynęły od wydania książki, pozostaje ona jedną z najczęściej umieszczanych na uniwersyteckich listach literatury najnowszej publikacji dotyczących Zagłady ${ }^{23}$. Jednak właśnie w przypadku ponawianych procesów (obowiązkowej, czyli niejako „przymusowej”) lektury tej powieści dostrzec można przemiany zbiorowej świadomości w kwestiach relacji polsko-żydowskich i żydowsko-polskich. Należy pamiętać, że w wypadku pierwszych roczników studentów czytających/omawiających Tworki możliwy był odbiór tej narracji poza historią Holokaustu ${ }^{24}$, dopiero później z wolna zmieniał się tryb lektury i zakres stawianych jej pytań ${ }^{25}$.

Uznając zasadność części z licznych głosów krytycznych, wypowiadanych z różnych pozycji metodologicznych i światopoglądowych, można jednak próbować odszukać tkwiący w powieści potencjał poznawczy - zasadzający się na rozbijaniu potocznych i wciąż powszechnych mechanizmów wypierania wiedzy o przyczynach i skutkach Zagłady. Mnożone w niej zabiegi narracyjne nie są bowiem celem samym w sobie, lecz służą odsłanianiu relacji z Innym, także przed

22 Zob. tamże, s. 243.

23 Zob. M. Tомсzок: „Opowiadanie jest stałym bytu cieniem”..., s. 86-87.

${ }^{24}$ Obserwuję te przemiany w praktyce akademickiej od roku wydania książki do chwili obecnej.

25 Od pytań „naiwnych”, a w istocie obnażających niewiedzę, takich jak np.: dlaczego Janka nie znała wielkanocnych zwyczajów świątecznych? z kim spotykała się Sonia, chodząc „za tory kolejowe"? co działo się w Hotelu Polskim? kim byli ludzie zaczepiający Marcela w kolejce podmiejskiej?, studenci zaczęli przechodzić do pytań fundamentalnych: dlaczego Sonia popełniła samobójstwo? dlaczego rodzina Marcela wybrała drogę do Hotelu Polskiego? co czeka Jankę w powojennej rzeczywistości? 
czytelnikiem, który nie zdawał sobie sprawy ze swojej z nim bliskości. Przez krytyków i badaczy powieść zrazu wpisywana była w ówczesne polskie dyskusje na temat (języków) postmodernizmu, co rzetelnie zrekapitulował w swoim artykule Arkadiusz Morawiec, pisząc w roku 2005:

Autor Tworek poza pragnieniem uobecnienia straty, przywołania Innego, dąży do uobecnienia dyskursu nakierowanego na wypełnienie pustki, odczytanie imienia istnienia skazanego na niebyt i niepamięć. Świadomy tekstowego zapośredniczenia rzeczywistości, Bieńczyk nie popada jednak w jakiś językowy czy tekstowy solipsyzm, pantekstualizm ${ }^{26}$.

Utwór zdawał się przeznaczony dla elitarnego grona znawców literatury i zapewne tak by pozostało, gdyby nie gwałtowne przemiany zbiorowej polskiej samoświadomości ${ }^{27}$.

Przestrzeń wykreowana w Tworkach stała się specyficznym „miejscem autobiograficznym" ${ }^{\prime 28}$ autora, zaanektowanym i zinterioryzowanym w akcie twórczej ekspresji i autorefleksji. W miejscu poddawanym uważnemu, ale silnie subiektywizowanemu oglądowi przekształcana wielorako potoczna pamięć przeszłości oraz jej utrwalone $\mathrm{w}$ tradycji wizje współistnieją z krzyżującymi się na różnych poziomach współczesnymi dyskursami etycznymi, ideologicznymi i artystycznymi ${ }^{29}$. Cywilizacyjna katastrofa, która doprowadziła do gruntownego przeobrażenia znanego nam świata, pozostawiła puste miejsca domagające się wypełnienia, odtworzenia, przede wszystkim zaś podjęcia próby zrozumienia przebiegu minionych zdarzeń i wejścia w osobistą, osadzoną w aktualnych realiach relację z przeszłością - jej śladami, znakami, cieniami - konieczną, choć utrudnioną przez upływ czasu. Marek Zaleski, przypominając głęboko zakorzenione w świadomości zbiorowej przekonanie, że „umarli niepogrzebani należycie - wracają" ${ }^{30}$, wska-

${ }^{26}$ A. Morawiec: Holokaust i postmodernizm. O „Tworkach” Marka Bieńczyka. „Ruch Literacki” 2005, z. 2, s. 196.

${ }^{27}$ Dekadę po tekście Morawca temat relacji Zagłady i postmodernizmu (oraz kultury popularnej) podjął Bartosz Dąbrowski, który za exemplum swoich rozważań obrał Ziarno prawdy, powieść kryminalną Zygmunta Miłoszewskiego (B. DĄвRowsкi: Zagłada, postmodernizm, kanon i literatura popularna. „Narracje o Zagładzie” 2015, nr 1, s. 31-45).

${ }_{28}$ Zob. M. Czermińska: Miejsca autobiograficzne. Propozycja $w$ ramach geopoetyki. „Teksty Drugie" 2011, nr 5, s. 183-200. Badaczka wskazuje, że miejsce autobiograficzne można dookreślić jako indywidualne miejsce pamięci, którego niezbywalnym atrybutem jest jego jednostkowy wymiar, odniesienie do świadomie wytwarzanej tożsamości. Nadto jest ono znaczeniowym oraz symbolicznym odpowiednikiem autentycznego miejsca geograficznego oraz związanych z nim kulturowych wyobrażeń.

${ }^{29}$ O kategorii przestrzeni w Tworkach pisałam w artykule $W$ cudzej przestrzeni - narracyjne gesty (samo)poznania w prozie przełomu XX i XXI wieku. „Białostockie Studia Literaturoznawcze" 2016, nr 8, s. 169-182.

${ }^{30}$ M. ZALeski: Rozmowa żywych $z$ umarlymi. W: TenżE: Echa idylli w literaturze polskiej doby nowoczesności i późnej nowoczesności. Kraków 2007, s. 46. 
zywał na przyczyny niedostatecznej reprezentacji traumatycznych doświadczeń wojny w literaturze powstającej po jej zakończeniu. Umarli nie mogli znaleźć odpowiedniego miejsca w tekstach, ponieważ silniejszy okazywał się mechanizm zapomnienia służący życiu, wzmacniany przez rzeczników zwycięskiej wówczas ideologii. Utraceni bliscy okazywali się też na rozmaite sposoby „niesłusznymi” umarłymi, o których należało zapomnieć dla własnego bezpieczeństwa czy choćby spokoju. Przede wszystkim jednak umarli nie znaleźli swojego miejsca w przestrzeni pamięci, ponieważ piszący od początku mieli świadomość niewydolności języka, niezdolnego wyrażać minione doświadczenia ${ }^{31}$.

Z dzisiejszej perspektywy najważniejszym aspektem późniejszego utrzymywania pokładów niepamięci w obrazowaniu Zagłady okazał się długo usuwany ze sfery świadomości zbiorowej fakt, że traumatyczna historia nie wydarzyła się wyłącznie pomiędzy Niemcami i Żydami. Pojawiła się konieczność ponownego utekstowienia przestrzeni, w której rozegrała się tragedia wpisywana odtąd w schemat trójkąta - nierównobocznego, ale jednak o trzech wierzchołkach. Tym samym także podjęcie tematu stawało się z reguły równoznaczne $\mathrm{z}$ wpisaniem się autora w ramy jednego z wielu współistniejących, jednak coraz bardziej sprzecznych, a nawet wykluczających się dyskursów pamięci o przeszłości. Pod koniec pierwszej dekady XXI wieku Katarzyna Bojarska, podsumowując liczne diagnozy powstające w obrębie polskiej odmiany kultury posttraumatycznej z przełomu tysiącleci, wskazała istotę przełomu w zbiorowym myśleniu o Zagładzie, choć tworząc tę zobiektywizowaną konstatację, nie mogła przewidzieć konsekwencji, jakie ów fakt będzie miał dla życia zbiorowego w kolejnych latach:

Gdyby ta traumatyczna historia wydarzyła się tylko między Niemcami a Żydami, byłaby łatwiejsza do zniesienia. Przez to, że brali w niej udział Polacy - świadkowie, ofiary, a niekiedy oprawcy (pośredni i bezpośredni) - sprawa jest bardziej skomplikowana, szczególnie dla pokoleń powojennych. Wchodzą one w posiadanie dziedzictwa, które nie jest ani jednoznaczne, ani chwalebne, natomiast wymaga rozliczenia i oceny, również krytycznej ${ }^{32}$.

Już jednak u schyłku XX wieku, w warunkach rozpadu wszelkich mitów spajających wspólnotę, niepokój mógł budzić fakt, że rozliczeń takich można było dokonywać przede wszystkim jako osobiście przeprowadzanych rozpoznań, czynionych we własnym imieniu.

Narrator powieści Marka Bieńczyka eksplicytnie ujawnia swą jednostkową, ale wychyloną ku zbiorowości perspektywę:

31 Zob. tamże, s. 44.

32 K. Bojarska: Historia Zagłady i literatura (nie)piękna. „Tworki” Marka Bieńczyka w kontekście kultury posttraumatycznej. „Pamiętnik Literacki” 2008, R. 99, z. 2, s. 93. 
Przychodzę więc nawoływany, przesyłkę odbieram, własnym podpisem ten nieproszony, nieadresowany dar na tylu stronach kwituję i wołam was, bo może i z was ktoś przyjdzie, ktoś przybędzie na stałe do mojej ławeczki, wołam, tak, przyjedźcie najlepiej wszyscy w dowolnym czasie, który będzie się stawał, przyjedźcie ze wszech stron jakąkolwiek kolejką ${ }^{33}$.

Narrator stale wskazujący na swoją obecność we współczesnych Tworkach, niepozwalający zapomnieć o sobie piszącym opowieść o Soni na ławeczce w przyszpitalnym parku, wzywa jednocześnie: „[...] czytajcie, czytajcie proszę, i święćcie imię wasze i pokwitujcie" ${ }^{34}$. Inaczej mówiąc - ujawnijcie własną kontrsygnaturę literackiej wizji. Tworki dzisiejsze stają się tym samym miejscem wielorako niejednorodnym: teraźniejszym i przeszłym, doświadczanym i utekstowianym, cudzym i własnym.

Wskazywanie przez autorów na rolę świadomości kreacyjnej, na wagę samego aktu artykułowania opowieści zawiera w sobie gest nawiązywania kontaktu z odbiorcą na nowych zasadach. Jako przedstawiciele pokoleń niepamiętających czasów okupacji muszą oni uobecniać traumatyczne doświadczenia wojenne w znanym, rozpoznawalnym, a zatem i oswojonym kształcie, by kontrapunktowo (w stosunku do obszernego zbioru utrwalonych w tradycji sposobów przedstawienia) ponawiać akt poznania. Ujawniane sygnały procesu tworzenia narracji o wojennych losach bohaterów zderzane są z gorzką świadomością ograniczeń wynikających z rzeczywistego przebiegu historycznych wydarzeń. Autor nie może uratować swych postaci od niechybnej śmierci - narrator zaś staje się medium tej przepełnionej bezsilnym żalem pewności. W Tworkach zostało stematyzowane pragnienie wkroczenia w granice cudzej przestrzeni autokreacja pełni w nich funkcję służebną. Tym samym opowieść przekształca się w narrację nie tylko o końcu epoki i końcu świata, lecz także o ostatecznym kresie ocalającej, utrwalającej, pośredniczącej mocy tekstów kultury.

W dotkniętej erozją i narażonej na ostateczny rozpad rzeczywistości wszelkie afekty i emocje mogą być wyrażane jedynie za pomocą istniejących w ludzkiej mowie nieadekwatnych przybliżeń, ułomnych metafor, nieskutecznych elips. Zadaniem pozostaje gromadzenie dowodów (wrażeń, symptomów, domysłów) na istnienie faktyczności. Faktyczność natomiast - jak twierdził Ryszard Nycz wyczuwalna jest poprzez opór, jaki stawia siłą swego bezwładu działaniom podmiotu oraz plastycznością swej substancji jego władzom przedstawiania ${ }^{35}$.

${ }^{33}$ M. BIEŃCZYK: Tworki. Warszawa 1999, s. 194.

34 Tamże.

${ }^{35}$ Por. R. Nycz: „Wyrażanie niewyrażalnego” w literaturze nowoczesnej (wybrane zagadnienia). W: Literatura wobec niewyrażalnego. Red. W. Bolecki, E. Kuźma. Łódź 1998, s. 100. Badacz podkreślał w tym samym miejscu, że dla ponowoczesnej twórczości rzeczywistością byłaby przede wszystkim pozbawiona esencji materia realności; to, co nieuchwytne, bo bezkształtne, nieznaczne i nieznaczące. 
Negatywna obecność opierającej się uobecnieniu rzeczywistości dla sztuki staje się wyzwaniem, które może wypełniać, choć jedynie w ograniczonym zakresie. Pozostaje zatem świadectwo jednostkowej woli poszukiwania i stawiania pytań, przy równoczesnym uznaniu niemożności dotarcia do zobiektywizowanych odpowiedzi i przekroczenia aktu samopoznania.

W powieści Bieńczyka szpital w Tworkach ukazany został jako przestrzeń palimpsestowa: sceneria (wielokrotnie przetworzonych literacko) tragicznych wydarzeń sprzed półwiecza i współczesne miejsce pracy twórczej pisarza próbującego nawiązać kontakt z przeszłością dzięki usytuowaniu się w centralnym punkcie kreowanej (odnajdywanej, od-twarzanej) przez siebie historii. Katarzyna Bojarska podkreślała: „[...] kluczowe w Tworkach są właśnie sama opowieść i pamięć oraz próba odtworzenia nieistniejącego świata z nędznych resztek, jakie po nim zostały" ${ }^{36}$. Akt pisania pojmowany jako akt przywracania utraconych miejsc, zatartych śladów, ulotnych pozostałości staje się dzięki temu działaniem wymagającym rzeczywistego zaangażowania - to z kolei wiąże się z pragnieniem, by także odbiorcy uznali konieczność wejścia w tryb uważnej, aktywnej, a zarazem emocjonalnej lektury. Nade wszystko zaś, by autora i czytelników połączyło przekonanie o konieczności drążenia przeszłych wydarzeń, choćby wiązało się to ze zburzeniem zapewniających psychiczny komfort zafałszowań. Dlatego narrator powtarza: „[...] sygnujcie na nowo, potwierdźcie, pokwitujcie, podpiszcie kiedyś odbiór, dorzućcie, wy wszyscy dziś niby imienni, swoje post, postscriptum" 37 .

Twórcze „zmyślenie” zmienia się w zestaw zadań do wykonania. Aleksandra Ubertowska stwierdziła, że fikcję - domenę i tworzywo powieści Bieńczyka „należałoby rozumieć w szczególny sposób, jako swoisty mimetyzm formalny, naśladowanie różnych gatunków mowy, odsyłające do różnych form wypowiedzi, ugruntowanych w tradycji, również w obrębie historii literatury o Zagładzie"38. Zbudowała jednak swą krytyczną analizę na stwierdzeniu, że autor „usunął poza horyzont swojej świadomości pisarskiej dramatyczne, determinujące sytuację pisarza Szoa napięcie między historią i fikcją"39. Natomiast w Tworkach silne napięcie między historią a fikcją uwidacznia się właśnie na poziomie zderzania teraźniejszych reakcji opowiadającego z nieodwracalnym, wydobywanym z niepamięci przebiegiem minionych zdarzeń.

Historia jednego $\mathrm{z}$ bohaterów, Jerzego o nieznanym nazwisku, ukrywającego się pod fałszywym mianem Marcelego Brochwicza, skłania narratora do pełnej bezsilności apostrofy: „No właśnie Marcelu Jerzy, powiedzmy Brochwicz, gdzie poszedłeś? Gdzieżeś, kurwa, przepadł? Wo bist du gegangen, gekommen

${ }^{36}$ K. Bojarska: Historia Zagłady i literatura (nie)piękna..., s. 96.

${ }^{37}$ M. BıEŃCZYK: Tworki..., s. 194.

38 A. UbertowsKa: Świadectwo - trauma - głos. Literackie reprezentacje Holokaustu. Kraków 2007, s. 274.

39 Tamże, s. 295. 
i kaputt?"40. Protagonista, zmęczony życiem w ciągłym strachu, zdecydował się wraz z żoną i jej siostrą pójść do Hotelu Polskiego, gdzie Niemcy zastawili pułapkę na ukrywających się jeszcze członków żydowskiej społeczności. Wyprawa, która musiała zakończyć się tragicznie, prowokuje narratora do wyznania: „Marcelu Jerzy Brochwicz, weź sobie wszystko, co moje. Resztkę papierosa już zgasłego $\mathrm{w}$ cynowej popielniczce, tę butelkę whisky z czerwoną nalepką [...] bilet miesięczny na kolejkę, a z kuchni radio tranzystorowe" ${ }^{\text {"41 }}$. Pragnienie podarowania wielu zbędnych - i wówczas, i dziś - rzeczy jest w istocie wyrazem rozpaczy wywołanej przez niemożność zmiany biegu wydarzeń oraz konieczność uznania, że zbrodnia z przeszłości dokonać się musi także w świecie powieściowej fikcji.

Darem jeszcze bardziej ukonkretnionym jako gest z poziomu pisarskiej kreacji jest laptop, na którym powstaje opowieść: „I weź sobie, tu obok, z tej ławeczki, komputer z polską czcionką, jak polski, psiakrew, dlaczego akurat Polski był wasz hotel, żebym tylko widział twoje ręce, jak go bierzesz i pakujesz, i twoje oczy, i twoje zęby, gdy się do mnie uśmiechasz”"2. „Polski” komputer, fizyczne medium tworzonej fikcji, zostałby oddany bez żalu za choćby cień możliwości odmiany minionych zdarzeń. Tym samym fikcja (działanie i produkt niejako zastępczy) nie przesłania przeszłości, lecz nakazuje poszukiwać ukrytego w niej przekazu dotyczącego skrywanej i wypieranej wiedzy zarówno o przedwojennych, okupacyjnych, jak i współczesnych relacjach żydowsko-polskich ${ }^{43}$.

Napisane pod koniec XX wieku Tworki uznać można za swoisty „horror idylliczny”, którego wymiar poznawczy (oraz po części i warunkowo „ratowniczy") wymaga szczególnej aktywności odbiorcy - nie tylko epistemologicznej, ale nade wszystko emocjonalnej. Budzą autentyczną grozę, o ile czytelnik zdoła wejść $\mathrm{w}$ rezonans z narratorem i przedstawianą przez niego wizją. Marek Zaleski wskazywał, że tropy idylliczne - współtworzące jakoby „niestosownie” świat Tworek - w literaturze poświęconej Zagładzie służą wzmacnianiu zamierzonego efektu obcości: „[...] zderzenie radykalnie anty-idyllicznego świata $\mathrm{z}$ toposem arkadyjskiego locus amoenus daje skutek podwójny: wydobywa okrucieństwo

40 M. Bieńczyk: Tworki..., s. 127.

41 Tamże, s. 128.

42 Tamże, s. 128-129.

43 W przypadku powieści Bieńczyka aktualne pozostają zagadnienia etyczne towarzyszące twórcom piszącym o Zagładzie, zogniskowane według Ubertowskiej wokół kwestii „nagannej” pokusy łagodzenia grozy Holokaustu, opowieść o Wydarzeniu powinna bowiem „mieć charakter mowy »samoniszczącej«, niszczącej również ramy lektury, tak, by czytelnik (przyjmując rolę świadka deformacji, radykalnego zróżnicowania tekstu) doświadczył drastyczności opresji” (A. Ubertowska: Aporie, skandale, wyrwy w tekście. Etyka opowieści o Zagładzie. „Teksty Drugie” 2002, nr 1-2, s. 127). Trzeba jednak pamiętać, że odbiorca może zawsze, wbrew dyrektywom autora, uspójnić tekst, usuwając poza pole widzenia sygnały drastyczności (i) opresji. W praktyce dydaktycznej istotniejszym wyzwaniem niż odsłonięcie etycznych wskazań twórcy z reguły okazuje się problem wytyczenia granic i zasad etyczności odbioru. 
Holocaustu i nieprzystawalność doń literackiego przedstawienia" ${ }^{\prime 4}$. W powieści pozorna idylla ulega ostatecznemu zniszczeniu, giną też wszyscy ukazani jako piękni, dobrzy, barwni, radośni, a przede wszystkim niewinni.

$\mathrm{Na}$ zgliszczach cywilizacji pozostają niezdarny grafoman Jurek i zdolna do mimikry, „bezbarwna” Janka. Pozbawieni wyrazistych cech, odarci z właściwości Adam i Ewa tkwią w opustoszałych ruinach, a ich utracony świat będzie miejscem niemożliwym do odtworzenia ani $\mathrm{w}$ rzeczywistości, ani $\mathrm{w}$ sferze sztuki. Celem artystycznych zabiegów stać się musi zatem nie tylko uobecnianie tego, co bezpowrotnie zaprzepaszczone, ale także odkrywanie i jednoczesne wytwarzanie tożsamości własnej, ustanawianej w relacji z minionym czasem i w odniesieniu do utraconych przestrzeni, trudne dążenie do samopoznania: jako członka zbiorowości strzaskanej w czasie minionym i pozbawionej czasu przyszłego. Nasza tożsamość - jak przekonuje Zaleski - może stać się zakładnikiem opowieści: „To, co jest ostatecznym celem (obecność), w literaturze jest śladem (przedstawienie). Być to stawać się poprzez coraz to bardziej mnożące się znaki - ślady obecności. Im więcej znaków, tym silniejsze bycie”" ${ }^{35}$. Nie ma ucieczki przed świadomością, że „uobecnienie” Soni dokonać się może wyłącznie przez pracę żałoby. Natomiast gest pisania przyczynić się powinien do reintegracji podmiotowej tożsamości - nadawcy i odbiorcy fikcyjnego dzieła, połączonych przynależnością do wspólnoty, której dzieje nie niosą pocieszenia.

Tworki zyskują status miejsca autobiograficznego, pozwalającego zamknąć $\mathrm{w}$ swoich granicach doświadczenie tworzenia pojmowanego jako przezwyciężanie pustki i nicości, przekraczanie głębokiej wyrwy między usuwaną w niepamięć przeszłością a naznaczoną utratą teraźniejszością. Odbiorca może w tej drodze towarzyszyć autorowi - może jednak również wybrać gest odmowy. Od niego bowiem ostatecznie zależy, czy odnajdzie w otrzymanej fikcyjnej opowieści przebłyski przeszłości, odsłaniane, by zmieniać (uczyć) teraźniejszość. Wiedza o tym, jakie historie zdolne są poruszyć czytelnika, nakazuje ostrożność w ich kreowaniu, by nie ulec pokusie dokonywania manipulacji. Natomiast odszukiwanie śladów przeszłości, próba ich transpozycji okazuje się ostatecznie zadaniem niemożliwym do wykonania - nawet przy sprzęganiu ich z materią własnych doświadczeń - co jednak nie oznacza zwolnienia z obowiązku podejmowania kolejnych prób.

Koncepcje śladu, definiujące owo pojęcie jako formę obecności tego, co minione, zapomniane, wymykające się przedstawieniu lub utracone, wskazują nie tylko na związki śladu z kategorią pamięci jednostkowej czy zbiorowej, ale i na

${ }^{44}$ M. Zaleski: Jedyna instancja. W: TenżE: Echa idylli..., s. 277.

${ }_{45}$ Tamże, s. 308. Zaleski podkreśla w zakończeniu, że gdyby narrator miał oddać sprawiedliwość przeszłości, realiom Tamtego, dać im wyraz, musiałby wyjść poza język: „Poza przestrzeń języka, która jest przestrzenią ludzkiego. Lepiej pozostać w ludzkiej przestrzeni, zakończyć opowieść gestem afirmacji, niż zaciekle drążyć nieobecność: nigdy nie zdołamy oddać jej sprawiedliwości" (tamże, s. 310). 
jego immanentną niekoherencję oraz permanentną niestabilność. Utrwalane mimo to $\mathrm{w}$ niezliczonych tekstach kultury zdradzają wówczas swą podatność na zawłaszczanie $w$ ramach rozmaitych dyskursów i tendencję do zastygania w doraźnie przydatnych kształtach. Dlatego należy zapisywać je po wielekroć, $\mathrm{w}$ kolejnych księgach. Niemożność dotarcia do istoty rozpoznawanych w tekście znaczeń nie niweczy wagi i potrzeby ponawiania wysiłków. Można pojmować sens powtarzanych działań tak, jak proponował to Jacques Derrida na marginesie rozważań o Księdze pytań Edmonda Jabésa - jako równoczesność oraz tożsamość spotkania i rozstania ${ }^{46}$. Filozof, wskazując na niezbywalną rolę aktów zapisywania znaczeń, ponawiania prób ich pochwycenia, dążenia do przekroczenia ograniczeń poznawczych - przy jednoczesnej wiedzy, że wysiłki nie przyniosą, bo przynieść nie mogą, ostatecznego spełnienia - stwierdzał: „Między nazbyt żywym ciałem dosłownego zdarzenia i chłodną skórą abstrakcyjnych pojęć przebiega znaczenie. $\mathrm{W}$ ten właśnie sposób wchodzi do księgi. Wszystko zacho-

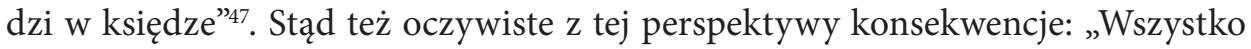
będzie musiało zamieszkać w księdze. Także księgi. Dlatego właśnie księga nie jest nigdy skończona. Zawsze cierpi i czuwa"48.

Powieść Tworki Marka Bieńczyka pozostaje nie tylko stałym punktem akademickich spisów lektur do nauczania zagadnień literatury najnowszej, okazuje się nade wszystko zamkniętym w fikcjonalnym kształcie probierzem zbiorowego postrzegania wspólnotowej historii i teraźniejszości. Uruchamiane strategie czytania/omawiania/interpretowania utworu odsłaniają aktualny etap rozwoju wiedzy o przeszłości, projektowania przyszłości i zakreślania zbiorowej tożsamości.

\section{Bibliografia}

BieńCZyk M.: Tworki. Warszawa 1999.

BojARska K.: Historia Zagłady i literatura (nie)piękna. „Tworki” Marka Bieńczyka w kontekście kultury posttraumatycznej. „Pamiętnik Literacki” 2008, R. 99, z. 2, s. $89-106$.

BuryŁa S., Krawczyńska D.: Proza. W: Literatura polska wobec Zagłady (1939-1968). Red. S. BuryŁa, D. Krawczyńska, J. Leociak. Warszawa 2016, s. 452-586.

Czapliński P.: Katastrofa wsteczna. „Poznańskie Studia Polonistyczne. Seria Literacka” 2015, nr 25, s. 37-66.

${ }^{46}$ Por. J. Derrida: Edmund Jabés i pytania księgi. Przeł. A. Wodnicki. „Literatura na Świecie" 2001, nr 7, s. 153.

47 Tamże, s. 155.

${ }^{48}$ Tamże. 
Czapliński P.: Zagłada jako horror. Kilka uwag o literaturze polskiej 1985-2015. „Zagłada Żydów. Studia i Materiały” 2016, nr 12, s. 375-394.

Czapliński P., Śliwiński P.: Literatura polska 1976-1998. Przewodnik po prozie i poezji. Kraków 1999.

Czermińska M.: Autor - podmiot - osoba. Fikcjonalność i niefikcjonalność. W: Polonistyka w przebudowie. Literaturoznawstwo - wiedza o języku - wiedza o kulturze - edukacja. Zjazd Polonistów, Kraków, 22-25 września 2004. T. 1. Red. M. CzermińsKA i in. Kraków 2005, s. 211-223.

Czermińska M.: Miejsca autobiograficzne. Propozycja $w$ ramach geopoetyki. „Teksty Drugie" 2011, nr 5, s. 183-200.

CzyżAK A.: W cudzej przestrzeni - narracyjne gesty (samo)poznania w prozie przełomu XX i XXI wieku. „Białostockie Studia Literaturoznawcze” 2016, nr 8, s. 169-182.

DĄBrowski B.: Zagłada, postmodernizm, kanon i literatura popularna. „Narracje o Zagładzie" 2015, nr 1, s. 31-45.

Derrida J.: Edmund Jabés i pytania księgi. Przeł. A. Wodnicki. „Literatura na Świecie” 2001, nr 7, s. 137-159.

Domańska E.: Historia ratownicza. „Teksty Drugie” 2014, nr 5, s. 12-26.

Gross J.T.: Sąsiedzi. Historia zagłady żydowskiego miasteczka. Sejny 2000.

KraWCZyńsKa D.: Wstęp. W: Literatura polska wobec Zagłady (1939-1968). Red. S. BuRY€A, D. KraWCZyńsKa, J. Leociak. Warszawa 2016, s. 10-26.

Łebrowska A.: Poznawanie siebie i poznawanie innego. Wobec inności literatury. W: Polonistyka w przebudowie. Literaturoznawstwo - wiedza o języku - wiedza o kulturze - edukacja. Zjazd Polonistów, Kraków, 22-25 września 2004. T. 1. Red. M. Czermińska i in. Kraków 2005, s. 238-252.

Morawiec A.: Holokaust i postmodernizm. O „Tworkach” Marka Bieńczyka. „Ruch Literacki" 2005, z. 2, s. 193-209.

NasıŁowskA A.: Literatura okresu przejściowego 1975-1996. Warszawa 2013.

Nycz R.: „Wyrażanie niewyrażalnego” w literaturze nowoczesnej (wybrane zagadnienia). W: Literatura wobec niewyrażalnego. Red. W. Bolecki, E. Kuźma. Łódź 1998, s. $79-100$.

Tомсzок M.: „Opowiadanie jest stałym bytu cieniem”. Kilka uwag o kanonie Zagłady w literaturze najnowszej. „Narracje o Zagładzie” 2015, nr 1, s. 75-95.

Tomczok M.: Złoto i dzieci. Polski horror ratowniczy. W: Historie i narracje. Od historii lokalnej do opowieści postantropocentrycznej. Red. R. MAKARsKA. Katowice 2019, s. $15-30$.

Ubertowska A.: Aporie, skandale, wyrwy w tekście. Etyka opowieści o Zagładzie. „Teksty Drugie” 2002, nr 1-2, s. 125-139.

UbertowskA A.: Świadectwo - trauma - głos. Literackie reprezentacje Holokaustu. Kraków 2007.

ZALESKi M.: Echa idylli w literaturze polskiej doby nowoczesności i późnej nowoczesności. Kraków 2007. 
Agnieszka Czyżak - dr hab., prof. UAM w Instytucie Filologii Polskiej Uniwersytetu im. A. Mickiewicza w Poznaniu. Zainteresowania badawcze: historia literatury współczesnej ze szczególnym uwzględnieniem literatury powstałej po roku 1989 oraz teoria literatury, przede wszystkim przemiany i rozwój badań kulturowych. Współredaktorka tomów zbiorowych, m.in.: Powroty Iwaszkiewicza (1999), Wariacje na temat (2003), PRL - świat (nie)przedstawiony (2010), Pokolenie „Współczesności”. Twórcy, dzieła, znaczenie (2016). Autorka książek: Życiorysy polskie 1944-89 (1997), Kazimierz Brandys (1998), Na starość. Szkice o literaturze przełomu tysiacleci (2011), Świadectwo rozproszone. Literatura najnowsza wobec przemian (2015) oraz Przestrzenie w tekście, w przestrzeni tekstów. Interpretacje (2018). 